\title{
Risk Factors of Postpartum Depression at Dr. Moewardi Hospital, Surakarta
}

\author{
Matilda Bupu Ria'), Uki Retno Budihastuti²), Aris Sudiyanto3) \\ 1)Masters Program in Public Health, Universitas Sebelas Maret \\ 2)Department of Obstetrics and Gynecology, Dr. Moewardi Hospital, Surakarta \\ 3)Faculty of Medicine, Universitas Sebelas Maret
}

\begin{abstract}
Background: Postpartum depression is one of the emotional disturbances that results from failure to postpartum psychological adaptation process. The global prevalence of postpartum depression is $10-15 \%$. This study aimed to analyze the risk factors of pregnancy on the incidence of postpartum depression.

Subjects and Method: This was an analytic and observational study with a cross-sectional design. The study was conducted at Dr. Moewardi hospital, from December 2017 to January 2018. A total sample of 150 postpartum mothers was selected for this study by exhaustive sampling. The dependent variable was postpartum depression (PPD). The independent variables were maternal age, stress, parity, unwanted pregnancy, type of labor, family income, family support, and domestic violence. The data were collected by questionnaire and analyzed by path analysis model.

Results: Postpartum depression was directly and positively affected by psychological stress $(b=$ $2.15 ; 95 \% \mathrm{CI}=1.17$ to $3.13 ; \mathrm{p}<0.001)$, delivery type $(\mathrm{b}=1.27 ; 95 \% \mathrm{CI}=0.32$ to $2.21 ; \mathrm{p}=0.008)$, and unwanted pregnancy $(\mathrm{b}=1.57 ; 95 \% \mathrm{CI}=0.57$ to $2.58 ; \mathrm{p}=0.002)$. Postpartum depression was directly but negatively affected by family income $(b=-1.52 ; 95 \% \mathrm{CI}=-2.51$ to $-0.54 ; \mathrm{p}=0.002)$, parity $(b=-1.24 ; 95 \% C I=-2.21$ to $-0.28 ; p=0.011)$, and family support $(b=-1.31 ; 95 \% C I=-3.28$ to $-0.24 ; p=0.016)$. Psychological stress increased with domestic violence $(b=2.68 ; 95 \% \mathrm{CI}=0.64$ to 4.73; $\mathrm{p}=0.010)$ and decreased with maternal age $(\mathrm{b}=-0.91 ; 95 \% \mathrm{CI}=-1.68$ to $-0.13 ; \mathrm{p}=0.022)$. Parity increased with maternal age $(b=1.66 ; 95 \% \mathrm{CI}=0.79$ to $2.53 ; \mathrm{p}<0.001)$. Domestic violence decreased with maternal age $(b=-1.34 ; 95 \% \mathrm{CI}=-2.85$ to $0.16 ; \mathrm{p}=0.081)$.

Conslusion: Psychological stress, delivery type, unwanted pregnancy, family income, parity, and family support, are direct risk factors for postpartum depression.
\end{abstract}

Keywords: Postpartum depression, unwanted pregnancy, domestic violence, family support

\section{Correspondence:}

Matilda Bupu Ria. Masters Program in Public Health, Universitas Sebelas Maret, Surakarta, Jl. Ir. Sutami No. 36 A, 57126, Surakarta, Jawa Tengah. E-mail: matildabupuria19@gmail.com.

Mobile +6281241254153 .

\section{BACKGROUND}

Pregnancy, childbirth, and being a mother, is a physiological process. Most women consider this process to be a pleasant phase of transition at a new stage in its life cycle. But this phase can be an undesirable process as a result of emotional disturbance during the post-partum period. One of the emotional disturbances in postpartum women is postpartum depression. Postpartum depression is a disturbance of feelings experienced by postpartum mothers as a result of failure in acceptance of psychological adaptation processes (Kenwa, Karkarta and Triyani, 2015).

The global prevalence of postpartum depression is $10-15 \%$. The prevalence of postpartum depression in Asian countries is high and varies with incidence rates of 26-85\%. Prevalence of postpartum depression in Indonesia is $50-70 \%$ of postpartum mothers (Taherifard et al., 2013). 
Postpartum depression can interfere with mother and infant interaction. Postpartum depression impairs maternal social function and quality of life. Postpartum depression can also result in short-term and long-term psychological disturbances that affect mother, child, husband, or other family members. In turn, it can impair mother and child love relationship, maternal attention in caring, nurturing, and raising children. Therefore, postpartum depression can adversely affect maternal and child health (Indriasari, 2017).

Depression can be easily recognized. But the mildest form of depression or slow appearance is often missed by patients and health workers because it is considered normal. Mothers with postpartum depression are often difficult to detect because they are reluctant to report symptoms of depression to health workers. A major problem in the treatment of postpartum depression is delayed early detection so that the patient does not receive adequate treatment (Patel et al., 2012).

A person's age can affect pregnancy. Pregnant women in the reproductive period have a smaller likelihood of having complications than women who are pregnant below or above the reproductive age (Marmi, 2014).

Family income is the amount of income earned by all members of the house and is used to meet the needs of the household. Family income may have an effect on the incidence of postpartum depression (Suparyanto, 2014).

Family support is an emotional bond between the family and the people around the mother. Forms of family support are emotional, informational, instrumental, and appraisal support (Motzfeldt et al., 2013).
Domestic violence is a maltreatment committed by husbands to their wives during pregnancy, whether physical, psychological, sexual, or economic violence (Janiwarty and Pieter, 2013).

The type of labor is divided into spontaneous/ normal labor and Caesarean section. Mothers with labor complication are at risk of developing postpartum depression (Oktarina, 2016; Ariyanti et al., 2016).

Unwanted pregnancy is one that is out of the will of the mother for a cause, whose existence is not desired by either party or both (Dewi and Sunarsih 2011).

Psychological stress is an event that forces a person to make adjustments or adaptations to the conditions experienced (Mashudi, 2013). Postpartum depression is a disturbance of feelings experienced by postpartum mothers as a result of failure in acceptance of the process of psychological adaptation (Kenwa et al., 2015).

The purpose of this study was to analyze the effects of age, family support during pregnancy, family income, domestic violence during pregnancy, type of labor, parity, unwanted pregnancy, and psychological stress on the incidence of postpartum depression.

\section{SUBJECTS AND METHOD \\ 1. Study Design \\ This was an analytic observational study with cross-sectional design.}

\section{Study Population and Sample}

The study was conducted at Dr. Moewardi Hospital, Surakarta, from December 2017 to January 2018. A total sample of 150 postpartum mothers day 1-10 was selected for this study by exhaustive sampling.

\section{Study Variables}

The dependent variable was postpartum depression. The independent variables were maternal age, psychological stress, 
parity, unwanted pregnancy, delivery type, family income, domestic violence, and family support.

\section{Operational Definition of Variable}

Maternal age was defined as the length of time the study subject life from birth to the time of the study. Data on maternal age was collected by questionnaire. Measurement scale was continuous, but for the purpose of data analysis it was transformed into dichotomous coded as follows, i.e. o for age $<35$ years old and 1 for age $\geq 35$ years old.

Family income was defined as the amount of income (in Rupiah) earned by all family members used for the fulfillment of daily needs, derived from self-employment, work on others, or other sources. Data on family income was collected by questionnaire. The measurement scale was continuous, but for the purpose of data analysis it was transformed into dichotomous coded as follows, i.e. $\mathrm{o}$ for low family income $<\mathrm{Rp}$ $1,534,985$ and 1 for high family income $\geq R p$ $1,534,985$.

Family support was defined as an emotional bond between the family and the people around the mother. Forms of family support are emotional, informational, instrumental, and appraisal support. The data was collected by questionnaire. Measurement scale was continuous, but for the purpose of data analysis it was transformed into dichotomous coded as follows, i.e. o for weak family support and 1 for strong family support.

Domestic violence was defined as the persecution perpetrated by husbands against wives during pregnancy, whether physical, psychological, sexual, or economic violence. Measurement scale was continuous, but for the purpose of data analysis it was transformed into dichotomous coded as follows, i.e. o for not experiencing domestic violence and 1 for experiencing domestic violence.
Delivery type was defined as the type of delivery process of a baby and the placenta, membranes, and umbilical cord from the uterus. The data were taken from the maternal and child monitoring book. Measurement scale was dichotomous, i.e. o for normal labor and 1 for Caesarean section.

Parity was defined as the number of children born by study subject. Parity was measured by questionnaire. The measurement scale was dichotomous, i.e. o for primipara and 1 for multipara.

Unwanted pregnancy was defined as one that is out of the will of the mother for a cause, whose existence is not desired by either party or both. The data was collected by questionnaire. The measurement scale was dichotomous, i.e. o for wanted pregnancy and 1 for unwanted pregnancy.

Psychological stress was defined as a condition experienced by postpartum mother when there was a discrepancy between the demands received with the ability to overcome it, resulting in psychological pressure. Psychological stress was measured by Kessler Psychological Distress Scale. The masurement scale was continuous, but for the purpose of data analysis it was transformed into dichotomous coded as follows, i.e. o for not experiencing psychological stress (score $<20$ ) and 1 for experiencing psychological stress (score $\geq 20$ ).

Postnatal depression was defined as a psychological adaptation disorder that occurs in postpartum mothers within seven days to one month after delivery. Postpartum depression would result in postpartum mothers being unable to care for themselves and their babies, even to commit suicide. Postpartum depression was measured by Edinburgh Postnatal Depression Scale questionnaire. The measurement scale was continuous, but for 
Journal of Maternal and Child Health (2018), 3(1): 81-90

https://doi.org/10.26911/thejmch.2018.03.01.08

the purpose of data analysis it was transformed into dichotomous coded as follows, i.e. o for not experiencing postpartum depression $($ score $<10$ ) and 1 for experiencing postpartum depression (score $\geq 10$ ).

\section{Study Instrument}

The data were collected by questionnaire and maternal and child health monitoring book.

\section{Data Analysis}

The data were analyzed using univariate, bivariate by Chi Square test, and multivariate path analysis.

Tabel 1. Study subject characteristics

\begin{tabular}{|c|c|c|}
\hline Characteristics & $\mathbf{n}$ & $\%$ \\
\hline \multicolumn{3}{|l|}{ Maternal age } \\
\hline$<35$ years & 111 & 74.0 \\
\hline$\geq 35$ years & 39 & 26.0 \\
\hline \multicolumn{3}{|l|}{ Parity } \\
\hline$<2$ (primiparous) & 72 & 48.0 \\
\hline$\geq 2$ orang (multiparous) & 78 & 52.0 \\
\hline \multicolumn{3}{|l|}{ Puerperium day } \\
\hline Day $1-2$ (taking in phase) & 122 & 81.3 \\
\hline Day 3 - 10 (letting go phase) & 28 & 18.7 \\
\hline \multicolumn{3}{|l|}{ Maternal education } \\
\hline$<$ Senior high school & 68 & $45 \cdot 3$ \\
\hline$\geq$ Senior high school & 82 & $54 \cdot 7$ \\
\hline \multicolumn{3}{|l|}{ Maternal employment } \\
\hline Working at home & 89 & 59.3 \\
\hline Working outside the house & 61 & 40.7 \\
\hline \multicolumn{3}{|l|}{ Maternal religion } \\
\hline Muslim & 150 & 100.0 \\
\hline Non-muslim & $\mathrm{O}$ & O \\
\hline \multicolumn{3}{|l|}{ Family income } \\
\hline$<$ minimum regional wage & 99 & 66.0 \\
\hline$\geq$ minimum regional wage & 51 & 34.0 \\
\hline
\end{tabular}

Table 2 showed that most of the study subjects had high education level $\geq$ senior high school (54.7\%), 89 mothers (59.3\%) working at home, and family income $<$ minimum regional wage (66.0\%). All of the mothers were Muslim (100\%). Half of the study subjects did not experience postpartum depression (52\%) and multiparous

\section{Research Ethics}

The research ethics clereance for this study was obtained from the Research Committe at Dr. Moewardi Hospital. Research ethics included informed consent, anonimity, and confidentiality.

\section{RESULTS}

\section{Study subject characteristics}

Table 1 showed that 111 mothers (74.0\%) aged $<35$ years. As many as 78 mothers (52.0\%) were multiparous. As many as 122 mothers $(81.3 \%)$ were in the puerperium (the first to the second day).
78 (52.0\%). As many as 89 (59.3\%) mothers wanted their pregnancy, $90(60 \%)$ mothers had psychological stress, 128 (85.3\%) mothers did not experience domestic violence, mothers labor with complication 84 (56.0\%), and 103 (68.7\%) mothers received strong family support during pregnancy. 


\section{Univariate analysis}

Tabel 2. Univariate analysis of study subjects

\begin{tabular}{llcc}
\hline \multicolumn{1}{c}{ Variable } & \multicolumn{1}{c}{ Category } & Frequency & Percentage (\%) \\
\hline Maternal age & < 35 years & 111 & 74.0 \\
& $\geq 35$ years & 39 & 26.0 \\
Family income & <Minimum regional wage & 99 & 66.0 \\
Family support & $\geq$ Minimum regional wage & 51 & 34.0 \\
& Weak & 47 & 31.3 \\
Domestic violence & Strong & 103 & 68.7 \\
& Not experiencing domestic & 128 & 85.3 \\
Delivery type & violence & 22 & 14.7 \\
& Experiencing violence & 66 & 44.0 \\
Parity & Normal & 84 & 56.0 \\
& Sectio caesarea & 72 & 48.0 \\
Unwanted Pregnancy & Primipara & 78 & 52.0 \\
\multirow{2}{*}{ Psychological stress } & Multipara & 89 & 59.3 \\
\multirow{2}{*}{ Postpartum depression } & No & 61 & 40.7 \\
& Yes & 60 & 40.0 \\
& Low & 90 & 60.0 \\
& High & 72 & 48.0 \\
\hline
\end{tabular}

\section{Bivariate analysis}

Table 3 showed the results of bivariate analysis on the effect of each independent

Tabel 3. Bivariate analysis on the effect of each independent variable during pregnancy on postpartum depression

\begin{tabular}{|c|c|c|c|c|c|c|c|c|c|}
\hline \multirow{3}{*}{ Variable } & \multirow{3}{*}{ Category } & \multicolumn{4}{|c|}{ Postpartum depression } & \multirow{3}{*}{ OR } & \multicolumn{2}{|c|}{ 95\% CI } & \multirow{3}{*}{$\mathbf{p}$} \\
\hline & & \multicolumn{2}{|c|}{ No } & \multicolumn{2}{|c|}{ Yes } & & \multirow{2}{*}{$\begin{array}{c}\text { Lower } \\
\text { limit }\end{array}$} & \multirow{2}{*}{$\begin{array}{l}\text { Upper } \\
\text { limit }\end{array}$} & \\
\hline & & $\mathbf{n}$ & $\%$ & $\mathbf{n}$ & $\%$ & & & & \\
\hline Maternal age & $<35$ years & 52 & 46.8 & 59 & 53.2 & 0.44 & 0.21 & 0.95 & 0.033 \\
\hline \multirow{3}{*}{$\begin{array}{l}\text { Family } \\
\text { income }\end{array}$} & $\geq 35$ years & 26 & 66.7 & 13 & $33 \cdot 3$ & & & & \\
\hline & $\begin{array}{l}<\text { minimum } \\
\text { regional wage }\end{array}$ & 42 & 42.4 & 57 & 57.6 & 0.31 & 0.15 & 0.63 & 0.001 \\
\hline & $\begin{array}{l}\geq \text { minimum } \\
\text { regional wage }\end{array}$ & 36 & 70.6 & 15 & 29.4 & & & & \\
\hline Family & Weak & 14 & 29.8 & 33 & 70.2 & 0.26 & 0.12 & 0.54 & $<0.001$ \\
\hline support & Strong & 64 & 62.1 & 39 & 37.9 & & & & \\
\hline Domestic & No & 77 & 60.2 & 51 & 39.8 & 31.71 & 4.14 & 243.12 & $<0.001$ \\
\hline violence & Yes & 1 & 4.5 & 21 & 95.5 & & & & \\
\hline \multirow[t]{2}{*}{ Delivery type } & Normal labor & 46 & 69.7 & 20 & 30.3 & 3.74 & 1.88 & 7.42 & $<0.001$ \\
\hline & $\begin{array}{l}\text { With } \\
\text { complication }\end{array}$ & 32 & 38.1 & 52 & 61.9 & & & & \\
\hline \multirow[t]{2}{*}{ Parity } & Primipara & 30 & 41.7 & 42 & 58.3 & 0.45 & 0.23 & 0.86 & 0.015 \\
\hline & Multipara & 48 & 61.5 & 30 & 38.5 & & & & \\
\hline Unwanted & Yes & 61 & 68.5 & 28 & 31.5 & 5.64 & 2.76 & 11.54 & $<0.001$ \\
\hline Pregnancy & Yes & 17 & 27.9 & 44 & 72.1 & & & & \\
\hline Psychological & Low & 50 & 83.3 & 10 & 16.7 & 11.07 & 4.91 & 24.95 & $<0.001$ \\
\hline stress & High & 28 & 31.1 & 62 & 68.9 & & & & \\
\hline
\end{tabular}

The result of bivariate analysis showed that postpartum depression decreased with maternal age, family income, family variable on the dependent variable using Chi-Square test. 
Journal of Maternal and Child Health (2018), 3(1): 81-90

https://doi.org/10.26911/thejmch.2018.03.01.08

type, unwanted pregnancy, and psychological stress.

\section{Multivariate Analysis}

Figure 1 showed the goodness of fit of the model after respecification on the path analysis using the Stata 13 program. Statictics of path analysis can be seen in Table 4 .

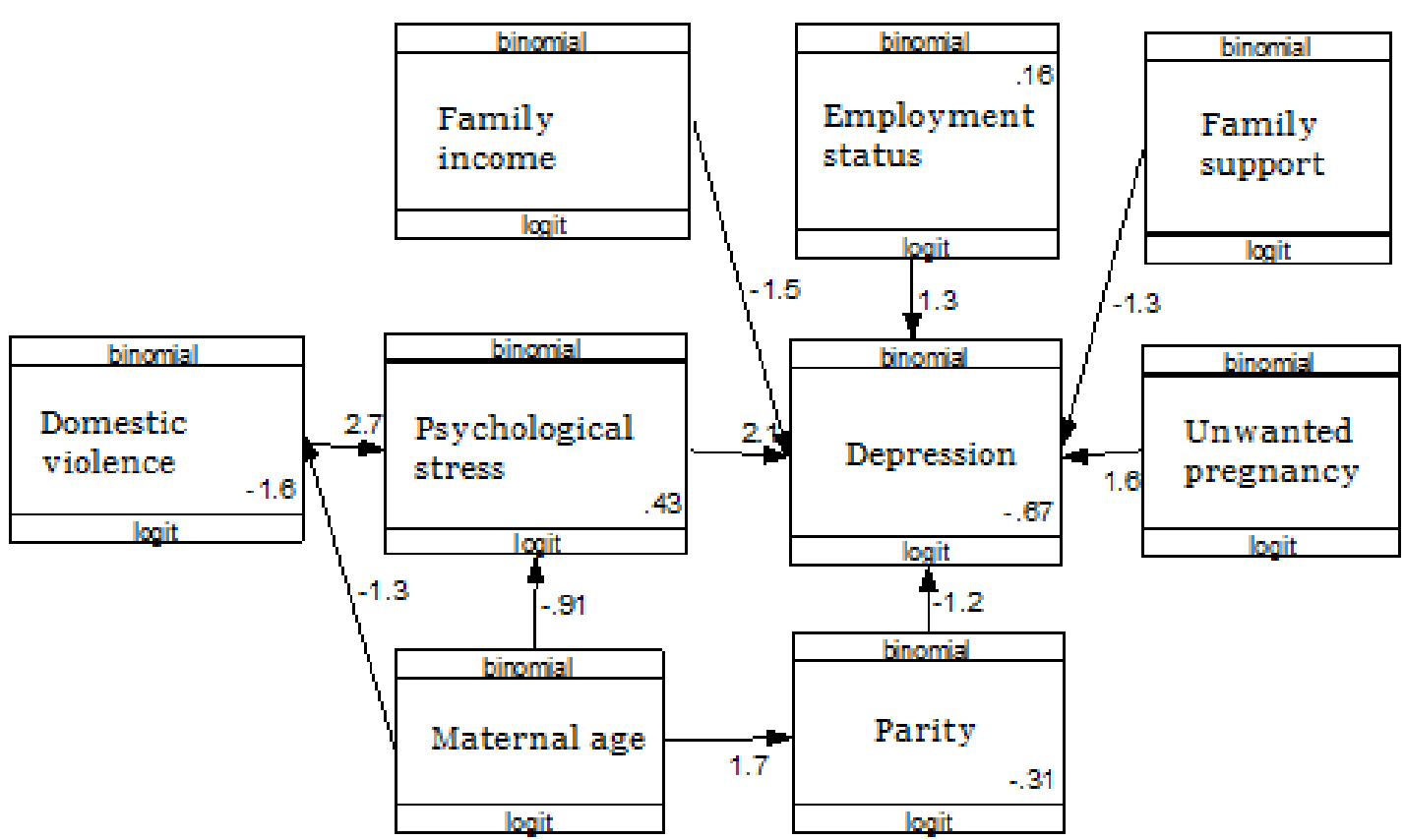

Figure 1. Fit model and parameter estimation of path analysis

Table 4. Path analysis on the effect of risk factors during pregnancy in postpartum depression

\begin{tabular}{|c|c|c|c|c|c|c|}
\hline \multirow[b]{2}{*}{ Dependent Variable } & & \multirow[b]{2}{*}{ Independent Variable } & \multirow[b]{2}{*}{$\mathbf{b}$} & \multicolumn{2}{|c|}{$95 \% \mathrm{CI}$} & \multirow[b]{2}{*}{$\mathbf{p}$} \\
\hline & & & & $\begin{array}{l}\text { Lowe } \\
\text { limit }\end{array}$ & $\begin{array}{c}\text { Upper } \\
\text { limit }\end{array}$ & \\
\hline \multicolumn{7}{|l|}{ Direct effect } \\
\hline Postpartum depression & $\leftarrow$ & Psychological stress & 2.15 & 1.17 & 3.13 & $<0.001$ \\
\hline Postpartum depression & $\leftarrow$ & Family income & -1.52 & -2.51 & -0.54 & 0.002 \\
\hline Postpartum depression & $\leftarrow$ & Parity & -1.24 & -2.21 & -0.28 & 0.011 \\
\hline Postpartum depression & $\leftarrow$ & Delivery type & 1.27 & 0.32 & 2.21 & 0.008 \\
\hline Postpartum depression & $\leftarrow$ & Family support & -1.31 & -2.38 & -0.24 & 0.016 \\
\hline Postpartum depression & $\leftarrow$ & Unwanted pregnancy & 1.57 & 0.57 & 2.58 & 0.002 \\
\hline \multicolumn{7}{|l|}{ Indirect effect } \\
\hline Psychological stress & $\leftarrow$ & Maternal age & -0.91 & -1.68 & -0.13 & 0.022 \\
\hline Psychological stress & $\leftarrow$ & Domestic violence & 2.68 & 0.64 & 4.73 & 0.010 \\
\hline Parity & $\leftarrow$ & Maternal age & 1.66 & 0.79 & 2.53 & $<0.001$ \\
\hline Domestic violence & $\leftarrow$ & Maternal age & -1.34 & -2.85 & 0.16 & 0.081 \\
\hline
\end{tabular}

Postpartum depression increased with psychological stress $(b=2.15 ; 95 \% \mathrm{CI}=$ 1.17 to $3.13 ; \mathrm{p}<0.001$ ), unwanted pregnancy $(b=1.57 ; 95 \% \mathrm{CI}=0.57$ to $2.58 ; \mathrm{p}=0.002)$, and delivery type $(\mathrm{b}=1.27 ; 95 \% \mathrm{CI}=0.32$ to 2.21; $\mathrm{p}=0.008)$.

Postpartum depression decreased with maternal age $(\mathrm{b}=-0.91 ; 95 \% \mathrm{CI}=-1.68$ to $-0.13 ; \mathrm{p}=0.022)$, parity $(\mathrm{b}=-1.24 ; 95 \%$ 
$\mathrm{CI}=-2.21$ to $-0.28 ; \mathrm{p}=0.011)$, higher family income $(b=-1.52 ; 95 \% \mathrm{CI}=-2.51$ to -0.54 ; $\mathrm{p}=0.002)$, and stronger family support $(\mathrm{b}=$ $-1.31 ; 95 \% \mathrm{CI}=-3.28$ to $-0.24 ; \mathrm{p}=0.016)$.

Psychological stress increased with domestic violence $(b=2.68$; CI 95\% $=0.64$ hingga $4.73 ; \mathrm{p}=0.010)$. Parity increased with maternal age $(b=1.66 ; 95 \% \mathrm{CI}=0.79$ to $2.53 ; \mathrm{p}<0.001)$. Domestic violence decreased with maternal age $(b=-1.34 ; 95 \%$ $\mathrm{CI}=-2.85$ to $0.16 ; \mathrm{p}=0.081$ ).

\section{DISCUSSION}

\section{The effect of maternal age on post- partum depression}

The results of path analysis in this study showed the relationship between maternal age and postpartum depression through parity. The effect is positive and statistically significant.

The higher maternal age, the higher the parity. The higher the parity, the lower the postpartum depression, because multiparous mothers have more experience in taking care of children than primiparous mothers. In addition, mothers aged $\geq 35$ years have a better coping mechanism to manage psychological stress so as to reduce psychological stress.

This study showed that postpartum depression was affected by maternal age and psychological stress. Mothers aged $\geq 35$ years were less likely to experience domestic violence, because young mothers are unable to make good decision, so that the husbands dominate the family. If domestic violence is persistent without treatment, the mother will experience postpartum depression.

This finding is consistent with Kusuma (2017) which reported that primiparous mother had a higher risk of postpartum depression than multiparous mother. A total of $47.1 \%$ study subjects aged 21-35 years had the risk of postpartum depression.

\section{The effect of family income on postpartum depression}

This study indicated that postpartum depression was directly and negatively affected by family income. Mothers with higher family income are less likely to have depression postpartum. Family income is a crucial thing that can affect a person's health. The higher family income, the better health condition.

Likewise, family income affects the health of postpartum mothers. Postpartum mothers with high family income are more able to meet their needs. Conversely, postpartum mothers with low family income have difficulty meeting their daily needs, which in turn impact on postpartum depression.

This study supported Dewi and Sunarsih (2011) that the financial factors affect the health of pregnant women. Pregnant women with low incomes are prone to illness, stress, and postpartum depression.

\section{The effect of family support on postpartum depression}

This study showed that postpartum depression was affected by family support. Mothers who received strong family support were less likely to experience postpartum depression than women who received weak family support.

In this study, most mothers under study received strong family support. Most mothers were less likely to experience postpartum depression because they got motivation from the family so that they felt calm and comfortable.

Support is the most powerful and consistent personal predictor of personal adjustment. The family is the primary source of support for postpartum women's health (Reid and Taylor, 2015). 


\section{The effect of domestic violence on postpartum depression}

This study indicated that postpartum depression was indirectly affected by domestic violence through psychological stress. Mothers who experienced domestic violence were more likely to experience postpartum depression than those who did not experience domestic violence.

Mothers who experience domestic violence during pregnancy will experience physical and psychological stress. If left untreated until delivery time, they may experience postpartum depression.

Domestic violence occurs about 7 $11 \%$ of pregnant women. Its effect on pregnant women can be either direct or indirect. Direct forms of domestic violence include trauma and physical injury to the mother and baby, for example, placental abruption, bone fracture, uterine rupture, and bleeding. Indirect forms of domestic violence are emotional reaction, anxiety, depression, and susceptibility to disease. Domestic violence can be a stressor either before or after childbirth, which may lead to postpartum depression (Dewi and Sunarsih, 2011).

\section{The effect of delivery type on postpartum depression}

This study showed that postpartum depression was directly and positively affected by delivery type. Mothers with labor complications were more likely to develop postpartum depression than those with normal delivery.

Mothers at risk of complicated pregnancy are encouraged to give Caesarian delivery. But Caesarean delivery heals longer than normal delivery, which can delay maternal recovery to daily activity and in turn increase the likelihood of stress and postpartum depression.

This finding is consistent with Mathisen et al. (2013), which put that mothers tend to assume that Caesarean delivery is a source of fear, stress, and trauma that can cause postpartum depression.

\section{The effect of parity on postpartum depression}

The study showed that postpartum depression was affected by parity. Multiparous mothers were less likely to experience postpartum depression than primiparous mother. This finding is consistent with Ibrahim et al. (2012), which reported that primiparous mothers experience higher postpartum depression than multiparous mothers. It is because multiparous mothers have experienced previous labor that reduces postpartum depression. On the other hand, labor event and being a mother with an infant caring role are new to primiparous mothers (Rusli et al., 2011). According to Dira and Wahyuni (2016), approximately $50-60 \%$ of mothers experience postpartum depression when they have their first child.

\section{The effect of unwanted pregnancy} on postpartum depression

This study showed that postpartum depression was affected by unwanted pregnancy. Mothers who underwent unwanted pregnancy were more likely to experience postpartum depression. Mother will become more indifferent to her pregnancy if it is not expected, which can increase the risk of postpartum depression (Alligood, 2013).

\section{The effect of psychological stress on postpartum depression}

Postpartum depression was positively affected by psychological stress during pregnancy. Pregnant mothers with psychological stress were more likely to experience postpartum depression. The psychological stress causes mothers to become incapable of adjusting her new role as a mother, which if left untreated can lead to 
postpartum depression.

Herlina (2014) found that psychological stress during pregnancy arouse due to family problem, such as changes in the living environment, family income hardship, and excessive workload. Excessive stress condition increases production of stress hormone, increases anxiety, reduces the coping mechanism, and increases postpartum depression (Fairus et al., 2014).

This study concludes that the risk of postpartum depression is affected by maternal age, parity, psychological stress, type of labor, unwanted pregnancy, family income, domestic violence, and family support.

\section{REFERENCE}

$\overline{\text { Alligood MR (2013). Nursing Theory Utili- }}$ zation and Application, Journal of Chemical Information and Modeling. doi:

10.1017/CBO9781107415324.004.

Ariyanti R, Nurdiati DS, Astuti DA (2016). Pengaruh Jenis Persalinan Terhadap Risiko Depresi Postpatum, Jurnal Kesehatan 'Samodra Ilmu', 7(2): 98105.

Dewi VNL, Sunarsih T (2011) Asuhan Kehamilan untuk Kebidanan. Jakarta: Salemba Medika.

Dira IKPA, Wahyuni AAS (2016). Prevalensi dan Faktor Risiko Depresi Postpartum di Kota Denpasar Menggunakan Edinburgh Postnatal Depression Scale', E-jurnal medika, 5(7): 5-9.

Fairus M, et al. (2014). Hubungan Dukungan Suami Dengan Kejadian Depresi Postpartum Pada Ibu Nifas, Jurnal Kesehatan Metro Sai Wawai, 7(1): 1118.

Herlina YN (2014). Hubungan Stresor Psikososial pada Kehamilan dengan Partus Prematurus, Jurnal Kesehatan
Andalans, 5(1): 129-134.

Ibrahim F et al. (2012). Faktor-Faktor yang Berhubungan Dengan Depresi Postpartum di RSIA Pertiwi Makassar Tahun 2012, (82).

Janiwarty B, Pieter HZ (2013) Pendidikan Psikologi untuk Bidan- Suatu Teori dan Terapannya. Yogyakarta: Andy Offset.

Kenwa P, Karkarta MK, Triyani IGA (2015). Pengaruh Pemberian Konseling Terhadap Depresi Post Partum di Puskesmas II dan IV Denpasar Selatan, COPING Ners Journal, 3(2).

Kusuma PD (2017). Karakteristik Penyebab Terjadinya Depresi Postpartum pada Primipara dan Multipara, Jurnal Keperawatan Notokusumo, 5(1): 3645.

Marmi (2014) Asuhan Kebidanan pada masa Antenatal. Yogyakarta: Celeban Timur UH.

Mashudi F (2013). Psikologi Konseling: Buku Panduan Lengkap dan Praktis Menerapkan Psikologi Konseling. Yogyakarta: IRCiSoD

Patel M, Bailey RK, Jabeen S, Ali S, Barker NC, Osiezagha K (2012). Postpartum Depression: A Review, Journal of Health Care for the Poor and Underserved, 23: 534-542.

Mathisen SE, et al. (2013). Prevalence and Risk Factors for Postpartum Depressive Symptoms in Argentina: A Cross- Sectional Study, International Journal of Women's Health, 5: 787793.

Motzfeldt I, et al. (2013). Prevalence of Postpartum Depression in Nuuk, Greenland Á a Cross-Sectional Study Using Edinburgh Postnatal Depression Scale, Int J Circumpolar Health, 1: 1-6.

Oktarina MM (2016). Faktor-Faktor yang Berhubungan dengan Potpartum 
Blues di Rumah Sakit Muhammadiyah Palembang, Jurnal MUSWIL IPEMI Jateng, 114-120.

Reid KM, Taylor MG (2015). Social Support, Stress, and Maternal Postpartum Depression: A Comparison of Supportive Relationships, Social Science Research. Elsevier Inc., 54: 246-262. doi: 10.1016/j.ssresearch.2015.08.009.

Rusli RA, Meiyuntariningsih T, Warni WE (2011). Perbedaan Depresi Pasca Melahirkan pada Ibu Primipara Ditinjau dari Usia Ibu Hamil, Jurnal INSAN, 13(1): 21-31.

Suparyanto (2014) Konsep Pendapatan
Keluarga. [Online] Tersedia: http//dr-supryanto.blogspot.com/2014/o3/ Dasarkonsep-dasar-pendapatankeluarga.httml. Diakses 21 Agustus 2017.

Taherifard P, et al. (2013). Socioeconomic, Psychiatric and Materiality Determinants and Risk of Postpartum Depression in Border City of Ilam, Western Iran, Journal of Hindawi Publishing Corporation. doi: 10.1155/2013/653471.

Indriasari S (2017). Tingkat Depresi Pada Ibu Postpartum di Puskesmas Morokrembangan Surabaya, Jurnal Dunia Keprawatan, 5: 43-49. 